\title{
Covalent Binding of Aminopropanehydroxydiphosphonate to Glutaraldehyde Residues in Pericardial Bioprosthetic Tissue: Stability and Calcification Inhibition Studies
}

\author{
Catherine L. Webb, ${ }^{1,2}$ Frederick J. Schoen, ${ }^{3}$ and Robert J. Levy ${ }^{1}$ \\ ${ }^{1}$ Section of Pediatric Cardiology, University of Michigan Medical Center, Research Laboratories, \\ Kresge II, Room 5014, Ann Arbor, Michigan 48109-0576; and ${ }^{3}$ Department of Pathology, Brigham \\ and Women's Hospital, Harvard Medical School, Boston, Massachusetts 02115
}

Received October 25, 1988, and in revised form January 13, 1989

\begin{abstract}
Calcification has limited the clinical utility of bioprosthetic heart valves fabricated from either glutaraldehyde-pretreated bovine pericardium or porcine aortic valves. Aminopropanehydroxydiphosphonate (APDP), covalently bound to residual aldehyde groups in glutaraldehyde-treated pericardial bioprosthetic tissue, has been shown to inhibit cardiovascular calcification in the rat subdermal model. Using ${ }^{3} \mathrm{H}$-labeled glutaraldehyde (GLUT) at a concentration of $0.02 M$ and $0.14 M{ }^{14} \mathrm{C}$-labeled APDP, we assessed the effects of GLUT

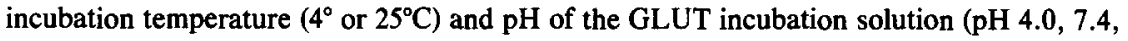
or 10.0) on the GLUT incorporation step and subsequent APDP binding (24 hr $25^{\circ} \mathrm{C}$ ) into bioprosthetic valve (BPV) tissue (bovine pericardium). Increased incorporation of GLUT and APDP occurred at lower GLUT incubation temperature (GLUT, 346.05 $\pm 1.9 \mathrm{nM} / \mathrm{mg}$, $4^{\circ} \mathrm{C}$ vs $259.76 \pm 1.39 \mathrm{n} M / \mathrm{mg}, 25^{\circ} \mathrm{C}$; APDP, $57.56 \pm 4.43 \mathrm{nM} / \mathrm{mg}, 4^{\circ} \mathrm{C}$ vs $36.36 \pm 0.46 \mathrm{nM} / \mathrm{mg}$, mean \pm standard error, at $25^{\circ} \mathrm{C}$ ). There also was a greater incorporation of GLUT but not APDP at the higher glutaraldehyde pretreatment $\mathrm{pH}$ (GLUT, $\mathrm{pH} 10.0,213.73 \pm 73 \mathrm{nM} / \mathrm{mg}$ vs $\mathrm{pH} 4,132.08 \pm 43 \mathrm{nM} / \mathrm{mg}$; APDP, $\mathrm{pH} 10.0,51.41 \pm 12 \mathrm{n} M / \mathrm{mg}$ vs $\mathrm{pH} 4.0,49.97 \pm 6$ $\mathrm{n} M / \mathrm{mg})$. In vivo studies revealed that all groups with treated BPV implanted for 21 days in male 3-week-old CD rats demonstrated a loss of both GLUT (12-50\%) and APDP (48-64\%) compared to preimplant content. BPV implant calcification was significantly inhibited in all groups treated with APDP compared to control $\mathrm{Ca}^{2+}(5.54 \pm 2.1-9.64+1.2 \mu \mathrm{g} / \mathrm{mg}$, APDP pretreated, vs $93.64 \pm 11.65 \mu \mathrm{g} / \mathrm{mg}$, control; $P \leqslant 0.001$ ) despite the progressive loss of both GLUT and APDP with time. It is concluded that preincubation of BPV tissue in GLUT at lower temperature $\left(4^{\circ} \mathrm{C}\right)$ and higher $\mathrm{pH}(10.0)$ enhanced BPV GLUT uptake and subsequent APDP covalent binding. In addition, in the rat subdermal model, BPV tissue calcification was markedly inhibited by APDP, despite a significant loss of bound drug. 1989 Academic Press, Inc.
\end{abstract}

\section{INTRODUCTION}

Calcific degeneration of bioprosthetic heart valves (BPV) fabricated from glutaraldehyde (GLUT)-pretreated porcine aortic valves and bovine pericardium has limited their widespread use in the surgical treatment of valvular heart disease ( 1 , 2). However, because of their central orifice flow characteristics and relative nonthrombogenicity compared to mechanical valves, tissue valves would be a desirable implant option, particulary in active children and adolescents and women of childbearing age $(1,2)$. Pathologic calcification of the bioprosthetic leaflet tissue has been studied experimentally both in orthotopic circulatory implants in sheep and calves and in subdermal implants in rats, mice, and rabbits. All of the experimental explants studied demonstrated pathology and bulk mineral accumulation comparable to that noted in clinicopathologic material.

\footnotetext{
2 To whom reprint requests should be addressed.
} 
In previous studies using the rat subdermal model of bioprosthetic tissue calcification, aminopropanehydroxydiphosphonate (APDP) pretreatment inhibited calcification of both porcine aortic valve and bovine pericardial BPV tissue $(3,4)$. The APDP was hypothesized in this prior work to covalently bond to residual aldehyde functions (noncrosslinked) in the bioprosthetic tissue thereby indicating the pathophysiologic importance of the glutaraldehyde-tissue interactions in this type of pathologic calcification. However, previous in vitro studies indicated the GLUT-APDP bonding to be unstable (6). Hence, the present paper reports the results of an extension of this research intended to optimize the use of APDP for inhibition of BPV calcification.

These experiments had as objectives: (i) characterization of the temperature and $\mathrm{pH}$ dependence of glutaraldehyde uptake by BPV tissue; (ii) assessment of the binding characteristics of APDP to BPV tissue after various glutaraldehyde pretreatment conditions; and (iii) assessment of the in vivo anticalcification efficacy and stability of APDP and glutaraldehyde using the rat subdermal model of BPV calcification.

\section{METHODS}

\section{Materials}

Analytic grade glutaraldehyde was obtained as an $8 \%$ aqueous solution (Polyscience, Warrington, PA). Buffers used for preparation of the glutaraldehyde incubation solutions included $0.05 M$ Hydroxyethylpiperazine- $N$-ethenesulfonic acid Hepes (Sigma Chemical CO., St. Louis, MO) or $0.05 M$ potassium phosphate (pH 7.4) in $0.9 \% \mathrm{NaCl}$ (Fisher Scientific, Fairlawn, NJ) for $\mathrm{pH} 7.4 ; 0.05 M$ sodium acetate $(\mathrm{pH} 4.0)$ in $0.9 \% \mathrm{NaCl}$ for $\mathrm{pH} 4.0$; and $0.05 \mathrm{M}$ sodium borate ( $\mathrm{pH} 10.0)$ in $0.9 \% \mathrm{NaCl}$ for $\left.\mathrm{pH} 10.0 .{ }^{3} \mathrm{H}\right]$ Glutaraldehyde (custom synthesized by New England Nuclear, Boston, MA as previously described (4)) was added to $0.2 \%$ nonradiolabeled glutaraldehyde to produce a solution with a final specific activity of 27.8 $\mathrm{dpm} / \mathrm{n} M$ GLUT. ${ }^{14} \mathrm{C}$-labeled and nonradiolabeled APDP were synthesized by Dr. James Benedict (Matrix Medical, Inc., Wheatridge, $\mathrm{CO}$ ) by reacting $\beta$-alanine with phosphorus trichloride in a diphosphonate condensation reaction (5) followed by hydrolysis of the cyclic condensation product. APDP was prepared as a $0.14 M$ aqueous solution in $0.05 M$ Hepes (Sigma Chemical Co.) buffer ( $\mathrm{pH}$ 7.4) with $0.9 \% \mathrm{NaCl}$ (Fisher Scientific), and synthesized ${ }^{14} \mathrm{C}$-labeled APDP was added to the nonradiolabeled APDP solution resulting in a specific activity of $12.5 \mathrm{DPM} /$ n $M$ APDP.

Parietal pericardium from mature bovines was obtained at slaughter and transported to the laboratory on ice. The pericardium was then rinsed free of blood in exhaustive volumes of iced sterile saline. Following this, pericardial fat was dissected from the parietal pericardium for use in the various $\left[{ }^{3} \mathrm{H}\right]$ GLUT incubation protocols (see below). Using a No. 7 cork borer, the pericardium was cut into 1 -cm-diameter pieces and prepared as previously described $(4,6)$.

\section{Glutaraldehyde $p H$ Variation}

Incubations of pericardial specimens at $\mathrm{pH} 4.0(0.05 \mathrm{M} \mathrm{Na}$ acetate, $0.9 \% \mathrm{NaCl}$, $0.2 \%\left[{ }^{3} \mathrm{H}\right]$ glutaraldehyde), pH $7.4(0.05 M$ Hepes, $0.9 \% \mathrm{NaCl}, 0.2 \%$ $\left[{ }^{3} \mathrm{H}\right]$ glutaraldehyde $)$ and $\mathrm{pH} 10.0(0.05 \mathrm{M} \mathrm{Na}$ borate, $0.9 \% \mathrm{NaCl}, 0.2 \%$ $\left[{ }^{3} \mathrm{H}\right.$ lglutaraldehyde) were compared. Group numbers correspond to Table I. All 
TABLE I

Characteristics of Explanted BPV Preincubated in GLUT and APDP

21-Day Rat Subdermal Implant

\begin{tabular}{|c|c|c|c|c|c|c|c|c|c|}
\hline \multirow[b]{2}{*}{ Group } & \multirow[b]{2}{*}{$N$} & \multirow{2}{*}{$\begin{array}{c}\text { GLUT } \\
\text { incubation } \\
\text { temperature } \\
\left({ }^{\circ} \mathrm{C}\right)\end{array}$} & \multirow{2}{*}{$\begin{array}{c}\text { GLUT } \\
\text { incubation } \\
\text { pH }\end{array}$} & \multirow{2}{*}{$\begin{array}{c}\text { Explant } \\
\mathrm{Ca}^{2+} \\
(\mu \mathrm{g} / \mathrm{mg})\end{array}$} & \multirow{2}{*}{$\begin{array}{l}\text { Percentage } \\
\text { residual } \\
\text { APDP }\end{array}$} & \multirow{2}{*}{$\begin{array}{l}\text { Percentage } \\
\text { residual } \\
\text { GLUT }\end{array}$} & \multicolumn{2}{|c|}{ APDP:GLUT } & \multirow{2}{*}{$\begin{array}{l}\text { Rat } \\
\text { growth } \\
\text { \%wt } \\
\text { gain }\end{array}$} \\
\hline & & & & & & & Preimplant & Explant & \\
\hline I & 10 & 25 & 4.0 & $9.64 \pm 1.25$ & 36 & 81 & 0.38 & 0.17 & 323 \\
\hline II & 10 & 25 & 7.4 & $7.55 \pm 0.82$ & 48 & 50 & 0.14 & 0.13 & 372 \\
\hline III & 9 & 25 & 10.0 & $8.31 \pm 1.34$ & 52 & 88 & 0.24 & 0.14 & 362 \\
\hline IV & 10 & 4 & 7.4 & $6.96 \pm 2.31$ & 39 & 59 & 0.17 & 0.12 & 317 \\
\hline \multirow{2}{*}{\multicolumn{10}{|c|}{ (No APDP) }} \\
\hline & & & & & & & & & \\
\hline $\begin{array}{l}\text { VI } \\
\text { (unimpl }\end{array}$ & $\begin{array}{c}10 \\
\text { inted) }\end{array}$ & - & - & $0.58 \pm 0.02$ & - & - & - & - & - \\
\hline
\end{tabular}

Note. Abbreviations used: APDP, aminopropanehydroxydiphosphonate; BPV, bioprosthetic valve tissue; $\mathrm{Ca}^{2+}$, calcium; GLUT, glutaraldehyde; $N$, number of specimens; wt, weight.

incubations were for 7 days. Group I: $\mathrm{pH} \mathrm{4.0,T}=25^{\circ} \mathrm{C}$; Group II: $\mathrm{pH} 7.4, T=$ $25^{\circ} \mathrm{C}$; Group III: $\mathrm{pH} 10.0, T=25^{\circ} \mathrm{C}$.

After this initial incubation in $\left[{ }^{3} \mathrm{H}\right]$ glutaraldehyde, the BPV specimens from Groups I-III were exhaustively washed in their specific incubation buffer without glutaraldehyde until background levels of ${ }^{3} \mathrm{H}$ were attained. The specimens were then incubated in $0.14 M\left[{ }^{14} \mathrm{C}\right] \mathrm{APDP}(0.05 \mathrm{M}$ Hepes, $0.9 \% \mathrm{NaCl})$, at $\mathrm{pH} 7.4$ for 8 days.

Samples from each group were then dried to a constant weight in a $100^{\circ} \mathrm{C}$ oven and digested in $1 \mathrm{cc}$ Protosol (New England Nuclear, Billerica, MA) with $100-\mu \mathrm{l}$ deionized water in a $55^{\circ} \mathrm{C}$ waterbath for $24 \mathrm{hrs}(3,6)$. The digests were then counted for ${ }^{14} \mathrm{C}$ and ${ }^{3} \mathrm{H}$ radioactivity in a Beckman LS3801 liquid scintillation counter (Beckman Instruments, Fullerton, CA). Glutaraldehyde and APDP contents were calculated from standard curves derived from a series of known glutaraldehyde and APDP concentrations. Glutaraldehyde incorporation and APDP incorporation were expressed in nanomoles per milligram dry weight of tissue. The remaining specimens in each group were implanted subcutaneously in male weanling rats for 21 days (see below).

\section{Glutaraldehyde Temperature Variation}

Pericardial specimens were prepared as described (above) and samples placed in three GLUT solutions. Specific conditions unique to each group are described below. The experimental group numbers also correspond to the Roman numerals listed in Table I: Group IV, GLUT freshly prepared from stock stored at $4^{\circ} \mathrm{C}$. Pericardium incubated for 7 days at $4^{\circ} \mathrm{C}$, then reacted with APDP (see below). Group V, GLUT freshly prepared from stock stored at $4^{\circ} \mathrm{C}$ and not exposed to APDP. Pericardium incubated for 7 days at $25^{\circ} \mathrm{C}$.

After 7 days of GLUT incubation, the pericardial pieces were removed from the above solutions and washed extensively. Glutaraldehyde-pretreated Group IV was placed in $0.14 M\left[{ }^{14} \mathrm{C}\right] \mathrm{APDP}$ in $0.05 M$ Hepes, $\mathrm{pH} 7.4, T=25^{\circ} \mathrm{C}$. Group V tissue was placed in $0.05 M$ Hepes, $\mathrm{pH} 7.4, T=25^{\circ} \mathrm{C}$. Both groups were incubated for 8 days.

Specimens from each of Groups IV and V were then prepared for digestion in Protosol and liquid scintillation counting as described (above), and the remaining 
specimens from each of the three groups were then implanted subcutaneously in young rats (see implant methods bclow).

\section{Implantation and Retrieval}

Three-week-old (50-60 g) male Sprague-Dawley rats (CD strain, Charles River Laboratories, Burlington, MA) were used. They were fed Lab Chow (Ralston Purina, St. Louis, MO). The rats were anesthetized by an intraperitoneal injection of ketamine $(0.01 \mathrm{mg} / \mathrm{g})$ and each animal received two separate pieces of the bovine pericardium prepared as per the above protocols. The pericardial pieces were placed in two subcutaneous pouches dissected in the ventral abdominal wall which were separated by at least $2 \mathrm{~cm}$.

After 21 days, the animals were sacrificed by an ovcrdose of sodium pentobarbital and the pericardial specimens retrieved. Blood sampling was performed by cardiac puncture at the time of sacrifice and the femurs were removed from representative animals from each group for assessment of bone morphology.

All animals have received humane care in compliance with the "Principles of Laboratory Animal Care" formulated by the National Society for Medical Research and the "Guide for the Care and Use of Laboratory Animals" prepared by the National Academy of Sciences and published by National Institutes of Health (NIH Publications No. 85-23, revised 1985). The study was approved by the Animal Use Committee of the University of Michigan.

\section{Tissue Calcium Analysis}

Explanted tissue was washed extensively in $0.9 \% \mathrm{NaCl}$ and deionized water, lyophylized, and minced to a fine powder. Calcium levels were determined on 2-3 $\mathrm{mg}$ tissue by atomic absorption spectroscopy (3) after $\mathrm{HCl}$ acid hydrolysis.

\section{Morphologic Analysis}

Following explantation, representative specimens of pericardial tissue were immediately placed in Karnovsky's fixative (7) at pH 7.2. At sacrifice, femurs of APDP-treated animals and controls were dissected free of attached muscle and fixed in $10 \%$ ncutral-buffercd formalin. Spccimens of pcricardial tissuc and boncs were prepared for and examined by light microscopy as previously described (4).

\section{RESULTS}

Glutaraldehyde and subsequent APDP tissue incorporation was enhanced by carrying out the BPV glutaraldehyde preincubation step at lower temperature $\left(4^{\circ} \mathrm{C}\right)$ and higher $\mathrm{pH}(10.0)$. Although significant amounts of both GLUT and APDP leached out of the tissue after a 21-day in vivo implant (Fig. 1), calcification of the BPV tissue was significantly inhibited at all levels of APDP and GLUT incorporation. Finally, no evidence of diphosphonate toxicity was detected by microscopic analysis of the rat femurs (data not shown) or by group comparisons of rat growth.

\section{Effect of Temperature and $\mathrm{pH}$ on Uptake (in vitro)}

As shown in Fig. 1a, a greater amount of glutaraldehyde was incorporated into the BPV tissue at the lower incubation lemperature $\left(4^{\circ} \mathrm{C}\right)$ when compared to the samples incubated at room temperature $(346.05 \pm 1.90 \mathrm{nM} / \mathrm{mg}$ vs $259.76 \pm 1.39$ 


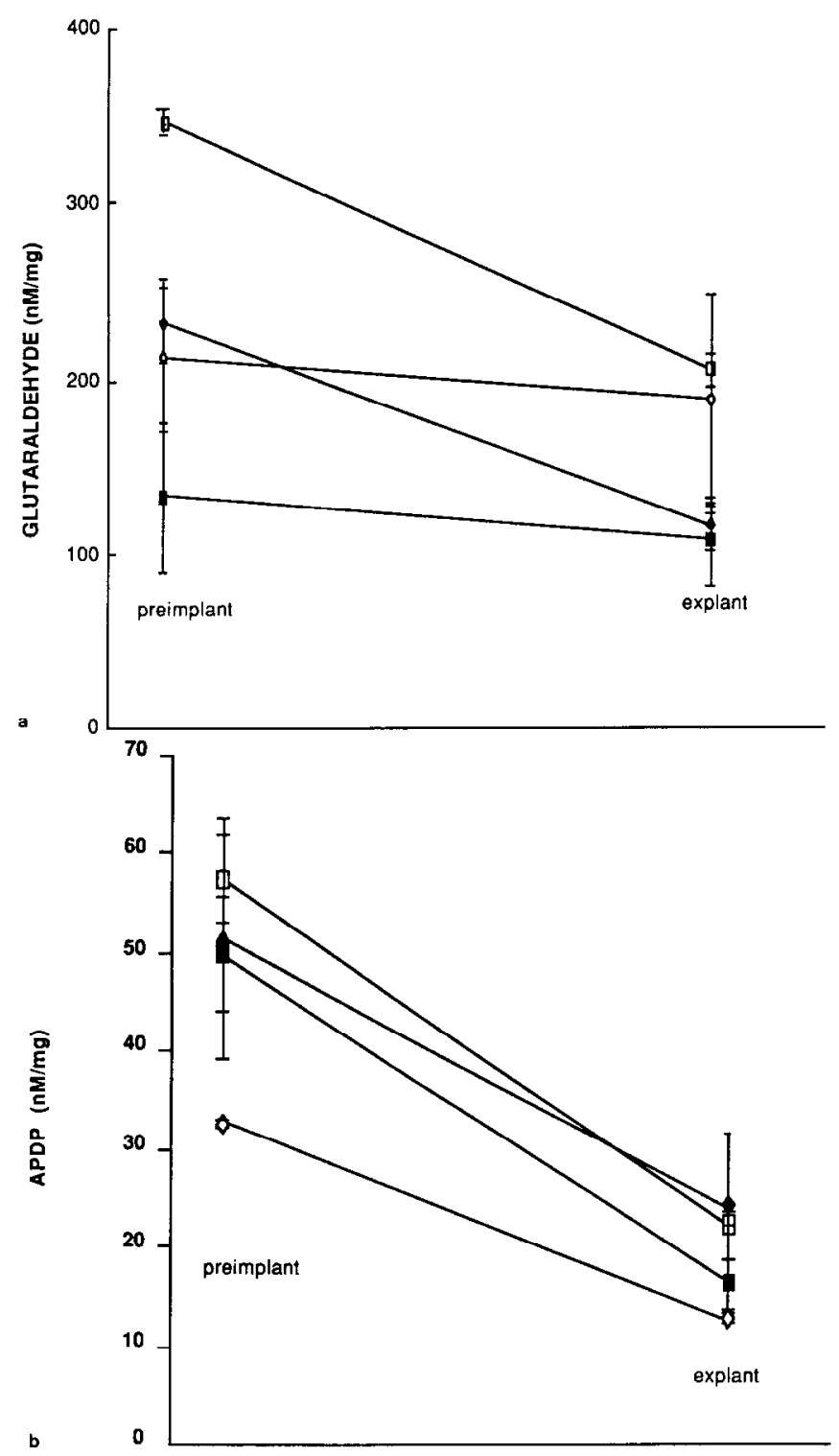

FIG. 1. Dissociation of glutaraldehyde and aminopropanehydroxydiphosphonate (APDP). Glutaraldehyde-pretreated bioprosthetic valve tissue subsequently preincubated in APDP, then implanted subcutaneously in weanling male rats (CD, Sprague-Dawley, 50-60 g) for 21 days. Tissue levels of glutaraldehyde and APDP before implant and after explant, showing a decrease after a 21-day implant. Group numbers correspond to Table 1. (a) Dissociation of glutaraldehyde: $\square$, incubation $T=4^{\circ} \mathrm{C}, \mathrm{pH}$ 7.4 (Group IV); $\diamond$, incubation $T=25^{\circ} \mathrm{C}, \mathrm{pH} 7.4$ (Group II); $\diamond$, incubation $T=25^{\circ} \mathrm{C}, \mathrm{pH} 10.0$ (Group III); $\square$, incubation $T=25^{\circ} \mathrm{C}$, pH 4.0 (Group I). (b) Dissociation of APDP: $\square$, incubation $T=4^{\circ} \mathrm{C}, \mathrm{pH}$

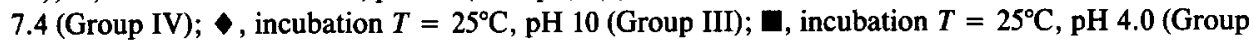
I); $\diamond$, incubation $T=25^{\circ} \mathrm{C}$, pH 7.4 (Group II).

$\mathrm{n} M / \mathrm{mg}$ ). Paralleling this, a greater amount of APDP was subsequently bound to GLUT-pretreated tissue which had been previously incubated at lower temperature (57.56 $\pm 4.43 \mathrm{nM} / \mathrm{mg}\left(4^{\circ} \mathrm{C}\right)$, vs $36.36 \pm 0.46 \mathrm{nM} / \mathrm{mg}\left(25^{\circ} \mathrm{C}\right)$ ) (Fig. 1b). However, the ratio of bound APDP:GLUT was 0.16 for the $4^{\circ} \mathrm{C}$ group vs 0.14 for the 


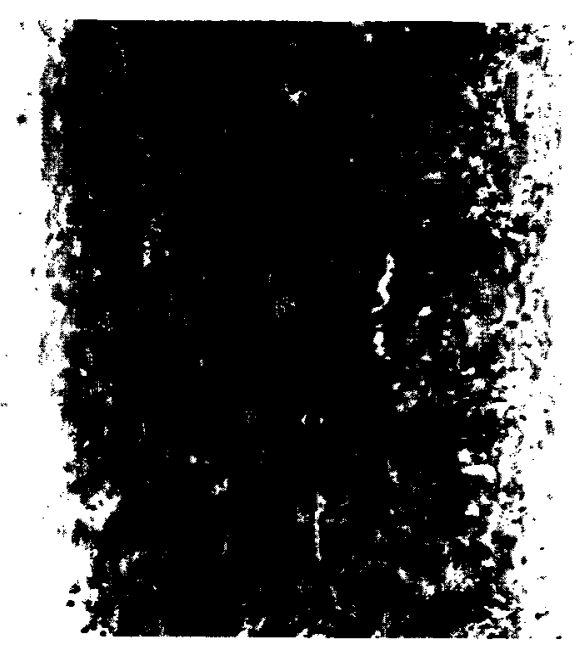

()
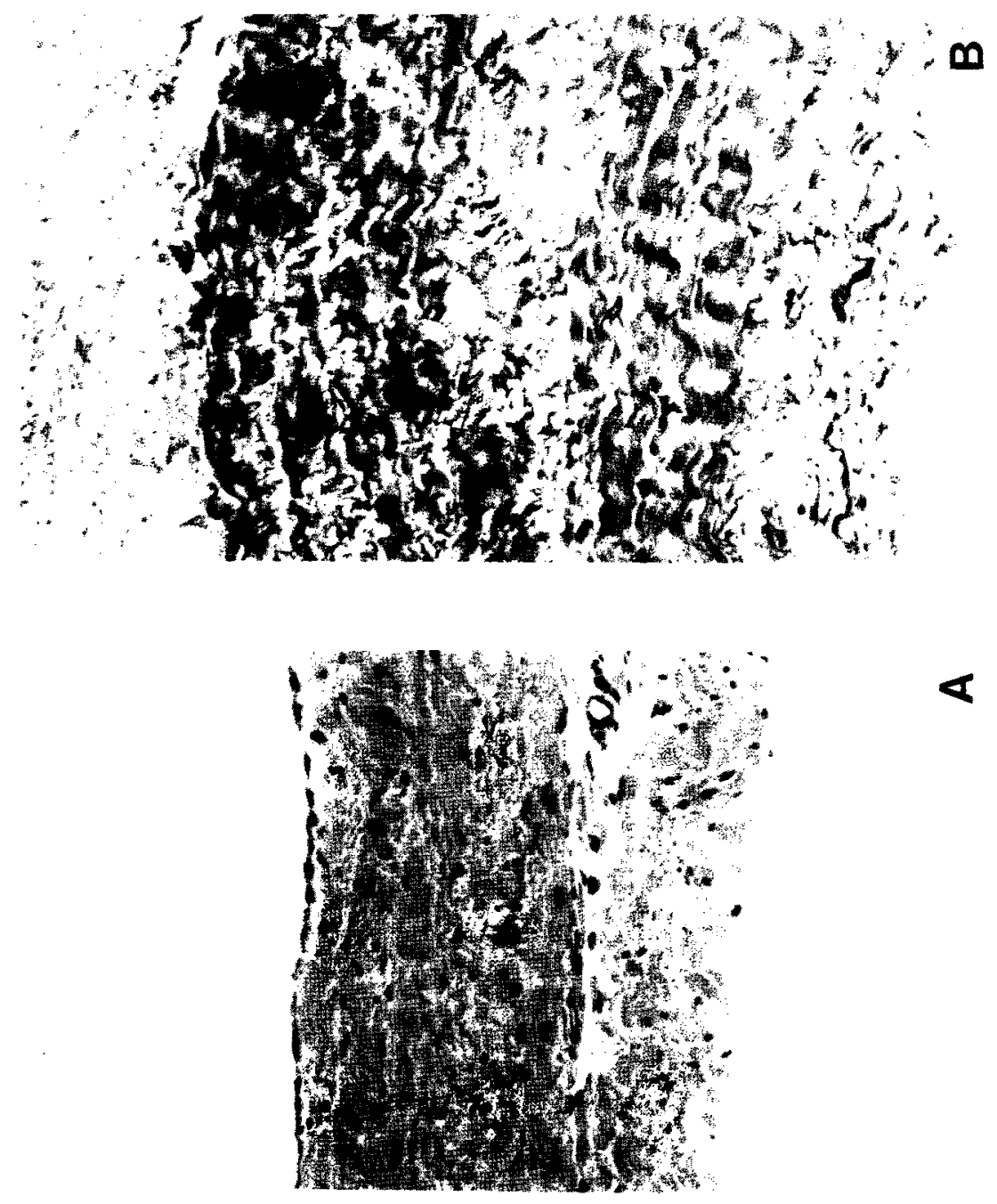

$+$ 
$25^{\circ} \mathrm{C}$ group (Table I) indicating the dependency of APDP binding on BPV aldehyde content.

In general, tissue incorporation of GLUT was pH dependent, with greater amounts being incorporated into the BPV tissue at higher $\mathrm{pH}$ (Fig. 1a). Bound APDP was $49.97 \pm 5.68 \mathrm{nM} / \mathrm{mg}$ in tissue previously incubated in glutaraldehyde at $\mathrm{pH} 4.0$, while it was $51.41 \pm 12.33 \mathrm{nM} / \mathrm{mg}$ in tissue previously incubated in glutaraldehyde at $\mathrm{pH} 10.0$ (Fig. 1b). Thus, although greater levels of GLUT incorporation are possible at higher $\mathrm{pH}$, the reactivity of the bound GLUT with APDP was apparently relatively diminished.

\section{In Vivo Inhibition of Calcification by APDP}

Tissue calcification was profoundly inhibited in explanted tissue from all experimental groups (both temperature and $\mathrm{pH}$ ) treated with APDP. Explanted tissue $\mathrm{Ca}^{2+}$ values were slightly higher than those of unimplanted tissue $(0.58 \pm 0.02$ $\mu \mathrm{g} / \mathrm{mg})$ and ranged from $5.54 \pm 2.08 \mu \mathrm{g} / \mathrm{mg}\left(T=25^{\circ} \mathrm{C}, \mathrm{pH} 7.4\right)$ to $9.64 \pm 1.25$ $\mu \mathrm{g} / \mathrm{mg}\left(T=25^{\circ} \mathrm{C}, \mathrm{pH} 4.0\right)$. Nevertheless, compared to the control value of 93.64 $\pm 11.65 \mu \mathrm{g} \mathrm{Ca}{ }^{2+} / \mathrm{mg}$, calcification in all APDP preincubated tissue groups was significantly inhibited (Table $I, P \leqslant 0.001$ ).

Light microscopic examination of the implanted tissues confirmed that calcification was virtually nonexistent in the specimens from Groups I to IV (Fig. 2). The specimens from Group V demonstrated diffuse and extensive mineralization of the central pericardial layer. In addition, the specimens from Group I $(\mathrm{pH} 4.0$, $T=25^{\circ} \mathrm{C}$ ) had, despite the lack of calcification, substantial homogenization of the connective tissue structure, likely due to autolysis, permitted by the relatively incomplete fixation of the acidic glutaraldehyde treatment (Fig. 3). All specimens from this group had a disruption of the normally observed discrete, wavy collagen bundles of the pericardial structure. Although cells were present between the collagen bundles, at the sites of the usual remnant pericardial fibroblasts, the exact morphology of these cells present in the specimens from Group I could not be determined due to the structural deterioration secondary to insufficient crosslinking.

\section{Glutaraldehyde and APDP Dissociation}

Although significant amounts of both GLUT and APDP leached out of the pericardial tissue during the 21-day rat implant (Fig. 1, Table I), relatively larger amounts of both GLUT and APDP remained in the explanted tissues which had initially been incubated in GLUT at $4^{\circ} \mathrm{C}$ compared to tissue which had been preincubated in GLUT at room temperature (Fig. 1, Table I). APDP:GLUT ratios in unimplanted tissue for incubation temperatures of $4^{\circ} \mathrm{C}$ and $25^{\circ} \mathrm{C}$ were 0.17 and 0.14 , respectively. After explant, tissue APDP:GLUT ratios for both temperature

FIG. 2. Photomicrographs of unimplanted bovine pericardium and bovine pericardium from APDPtreated and control groups following subdermal implantation for 21 days. (A) Unimplanted bovine pericardium demonstrating wavy, dense collagenous structure with interspersed connective tissue cells and blood vessels. (B) Pericardium from Group IV ( $T=4^{\circ} \mathrm{C}, \mathrm{pH} 7.4$, APDP treated). No mineralization is present. (C) Pericardium from Group $\mathrm{V}\left(T=25^{\circ} \mathrm{C}, \mathrm{pH} 7.4\right.$, no APDP). There is severe diffuse calcification. (A) Hematoxylin and eosin. (B, C) von Kossa stain (calcium phosphates black). Magnification, all $160 \times$. 

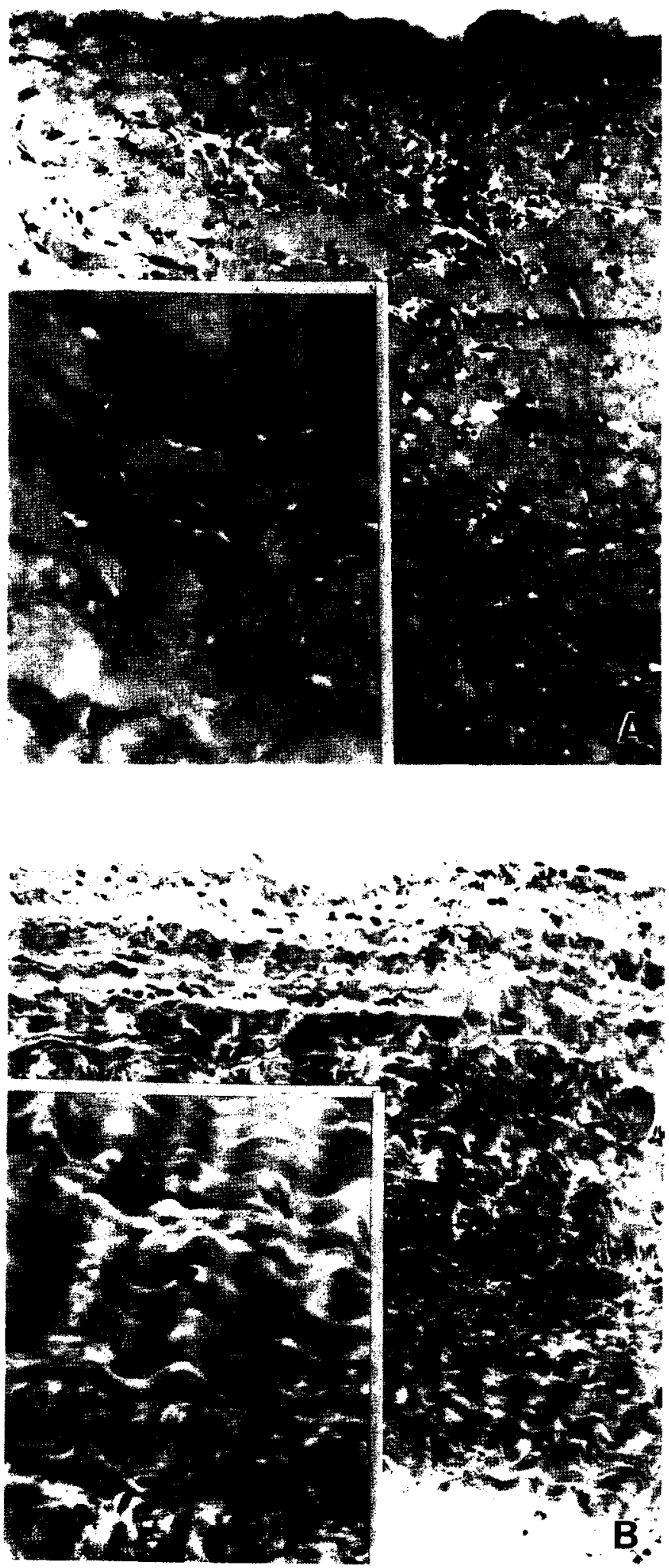
groups had decreased to $\mathbf{0 . 1 2}$ (Table I). Thus, there was a relatively greater loss of APDP compared to the loss of GLUT in explanted BPV tissue.

Additionally, tissue content of both GLUT and APDP decreased during the 21-day rat implant regardless of the $\mathrm{pH}$ at which the GLUT preincubation took place (Fig. 1, Table 1). Also, in all experimental groups, there was a relatively greater decrease in tissue APDP content compared to GLUT content in the explanted tissues as indicated by the APDP:GLUT ratios at explant (Table I). Thus, both APDP-GLUT dissociation and the loss of GLUT occurred, indicating the instability of both types of reaction products.

\section{Lack of Adverse Effects}

There were no detectable adverse effects caused by covalently bound APDP despite apparent in vivo dissociation. Rat growth over the 21-day period ranged from 256 to $372 \%$ of initial weight and was not affected by a subcutaneous implant of APDP-treated pericardial tissue (Table I). Distal femoral epiphyses from the animals in all of the experimental groups were without pathologic change compared to control (data not shown). The microscopic appearance of the distal femoral epiphyses from the experimental groups was comparable to that of the control.

\section{DISCUSSION}

Calcification of porcine aortic valve leaflets or bovine pericardium used in BPV is dependent, in part, on its pretreatment with glutaraldehyde; however, this pretreatment is necessary for tissue crosslinking and sterilization in order to prevent primary material failure $(8,9)$. Golomb et al., $(8)$ assessed the effects of GLUT incorporation into pericardial tissue and determined that at least $100 \mathrm{nM}$ GLUT/mg dry tissue was required for initiation of calcium deposition in the rat subdermal model. However, this prior work did not investigate the in vivo dissociation of glutaraldehyde shown in the present study.

Results of previous experiments dictated the design of the studies reported in this paper. APDP was chosen as the anticalcification agent because BPV preincubation in ethanehydroxydiphosphonate has been shown to be ineffective for calcification prevention (3). The length of incubation in GLUT (7 days) and the length of incubation in APDP ( 8 days) were chosen to correspond to previous experimental results (6), demonstrating maximal BPV incorporation of GLUT and APDP by 7 and 8 days, respectively.

Results of the present study have confirmed previous investigations in our laboratory demonstrating that the rat subdermal model provides an appropriate in vivo system to study the general process of pathologic calcification $(3,4,6)$. Most importantly, either glutaraldehyde-pretreated bovine pericardium or porcine aortic valve leaflets subdermally implanted in rats for 21 days accumulated calcium

FIG. 3. (A) Photomicrograph of pericardium from Group I (pH 4.0,T $=25^{\circ} \mathrm{C}$, APDP treated) demonstrating structural homogenization, likely due to incomplete original fixation resulting from suboptimal glutaraldehyde incorporation. (B) Adequately fixed implant from Group III (pH 10.0, T= $25^{\circ} \mathrm{C}$, APDP treated) for comparison. In (A), note the lack of the normal discrete, wavy collagen bundles which are present in (B). Cells are present between the collagen bundles, but these cells could be remnant from the original pericardial tissue or inflammatory cells of the rat, in which this tissue was implanted. Hematoxylin and eosin. Original magnification $150 \times$, insets $375 \times$. 
levels comparable to that measured in clinical specimens explanted for clinical failure after 36 to 156 months (18). Additionally, histologic examination of BPV explanted from rat subdermal implants demonstrated the same pathology as that seen in clinical explants (1-3). Interestingly, BPV tissue not pretreated with GLUT did not undergo calcification in this rat subdermal model, but merely underwent necrosis, thus emphasizing the importance of GLUT in this type of calcification. The bonding of an anticalcification agent such as APDP to BPVGLUT residues offered a direct means of examining the importance of noncrosslinked GLUT to the pathophysiology of BPV calcification.

The most important result of the present paper was the demonstration of the instability of the BPV tissue-glutaraldehyde bond during a 21-day in vivo exposure. This loss of glutaraldehyde tissue crosslinks implies the possibility of material instability over time, which may also enhance the calcification process and/or facilitate material-related BPV failure in the circulation. Moreover, the BPV GLUT-APDP bond was also unstable in vivo.

Mechanisms for glutaraldehyde binding to bioprosthetic tissue are complex and incompletely understood. Initial pathologic calcification of BPV implants is localized primarily intracellularly within fibroblasts and endothelial cells rendered nonviable by the glutaraldehyde pretreatment $(1,2)$. Subsequent calcium deposition involves structural proteins such as collagen $(1,2)$. Glutaraldehyde reacts primarily with free amino groups of proteins in the tissue (10). In the case of collagenous tissue such as pericardium, glutaraldehyde binding occurs almost entirely with the $\epsilon$ amino groups of lysine and hydroxylysine residues of the collagen molecule (11). Bowes and Cater have shown that approximately 4 to 5 moles of glutaraldehyde are taken up per lysine residue (11). However, not all of this is firmly bound, as elemental analysis of reaction products of glutaraldehyde-treated collagen suggests a ratio of three glutaraldehyde residues per lysine residue (11). Thus, these previous in vitro data may explain, in part, the in vivo loss of bound glutaraldehyde noted in the present study.

The present results also demonstrated that the glutaraldehyde-APDP bond was unstable over time in vivo. We hypothesized that the nature of this bond is a Schiff base, formed by the reaction of the amino terminus of APDP with a residual aldehyde group of glutaraldehyde $(11,12)$. As Schiff bases are relatively unstable at neutral $\mathrm{pHs}$, they may revert to the free amine and aldehyde upon an increase in temperature or a decrease in $\mathrm{pH}$ (12). In order to stabilize these Schiff bases, we theorized that conversion to secondary amines by reduction using a compound such as $\mathrm{NaBH}_{4}$ as a hydrogen donor would occur.

In a previous in vitro study, we treated BPV tissue, preincubated in glutaraldehyde and APDP, with $\mathrm{NaBH}_{4}$. Results showed that a greater amount of APDP was incorporated in the $\mathrm{BPV}$ tissue in the $\mathrm{NaBH}_{4}$-treated group than in the control at all time points ( 1 week, 3 months, 6 months) and at pH 4.0 as well as $\mathrm{pH} 7.4(6$, 13). This suggested that $\mathrm{NaBH}_{4}$ reduction may play a role in stabilizing the glutaraldehyde-APDP bond. Although in vivo studies have not yet been done, our in vitro results indicated that reduction of the GLUT-APDP bond by $\mathrm{NaBH}_{4}$ may be an effective preincubation strategy for tissue implants.

Results of the present study also indicated that the higher the $\mathrm{pH}$ and the lower the temperature of the glutaraldehyde incubation solution, the greater the amount of glutaraldehyde bound to BPV tissue. These findings may be due to the greater availability of collagen binding sites in the presence of the basic form of the lysine 
and hydroxylysine residues, as well as the absence of glutaraldehyde polymerization at lower temperature. The data reported here also indicated that although more glutaraldehyde was incorporated into BPV tissue when preincubated at $\mathrm{pH}$ 10.0, there was not a concomitant increase in the amount of APDP bound. This may be due to an increased amount of glutaraldehyde autopolymerization at higher $\mathrm{pH}$. Rasmussen and Albrechtsen have shown that the higher the $\mathrm{pH}$, the greater the degree of autopolymerization at the same temperature (14), and this is likely the reason for the lack of increased binding of APDP in spite of higher levels of BPV glutaraldehyde. It is possible that high molecular weight polyglutaraldehyde may provide more steric hindrance or perhaps fewer reactive aldehyde groups and thus prevent some APDP-GLUT binding which would otherwise have occurred with a reaction involving monomeric glutaraldehyde. Also, at lower $\mathrm{pH}$, greater amounts of APDP would be present in the acid form, and its amino terminus would thus be an ammonium residue which would not readily react with residual aldehyde groups.

Previously, we have shown that preimplant APDP tissue levels of $30 \mathrm{nM} / \mathrm{mg}$ or greater profoundly inhibited BPV tissue calcification in the rat subdermal model $(6,13)$. In the present study, all preimplant APDP tissue levels were found to be at least $30 \mathrm{n} M / \mathrm{mg}$. At explant less than half remained but calcification was still inhibited. With this result in mind, a feasible approach to prolonged inhibition of calcification may be the combined techniques of tissue preincubation in APDP with subsequent implantation of a controlled release matrix which would replenish tissue APDP as it leached out over time. In our laboratory, we have investigated such drug delivery systems, and the results of these studies (15-17) suggest that this combined approach of preincubation and sustained release drug delivery may be advantageous.

\section{CONCLUSION}

The results of these experiments have shown that preincubation of glutaraldehyde-treated BPV in APDP effectively inhibited BPV calcification in the 21-day rat subdermal model. BPV tissue uptake of GLUT was enhanced by tissue incubation at lower temperature $\left(4^{\circ} \mathrm{C}\right)$ and higher $\mathrm{pH}(10.0)$. However, reactivity of the bound GLUT with APDP was relatively diminished at higher $\mathrm{pH}$. After a 21-day rat subdermal implant, calcification in all APDP pretreatment groups (temperature and $\mathrm{pH}$ ) was significantly inhibited. Importantly, a significant amount of both APDP and GLUT leached out of the BPV tissue during the 21-day implant in all experimental groups, suggesting that sustained release APDP delivery may be necessary for long-term prevention of BPV calcification.

\section{ACKNOWLEDGMENTS}

This reasearch was funded in part by an American Heart Association of Michigan Research Fellowship, 1986-1988, for Dr. Webb and an NIH Grant R01-HL36574 for Dr. Levy. Dr. Levy is an Established Investigator of the American Heart Association. We gratefully acknowledge Catherine Wongstrom for help in preparation of the manuscript as well as the expert technical assistance of James Boyd. We also thank Dr. Sumner Barenburg of E. I. DuPont for providing assistance with the custom synthesis of $\left[{ }^{3} \mathrm{H}\right]$ glutaraldehyde.

\section{REFERENCES}

1. Schoen, F. J. (1987). Cardiac valve prostheses: Review of clinical status and contemporary biomaterials issues. J. Biomed. Mater. Res. Appl. Biomater. 21, 91-117. 
2. LeVY, R. J., Schoen, F. J., and GolomB, G. (1986). Bioprosthetic heart valve calcification: Clinical features, pathobiology and prospects for prevention. CRC Crit. Rev. Biocompat. 2(2), 147-186.

3. Levy, R. J., Hawley, M. A., Schoen, F. J., Lund, S. A., and Lıu, P. Y. (1985). Inhibition by diphosphonate compounds of calcification of porcine bioprosthetic heart valve cusps implanted subcutaneously in rats. Circulation 71, 349-356.

4. Schoen, F. J., TSAO, J. W., and LeVY, R. J. (1986). Calcification of bovine pericardium used in cardiac valve bioprostheses. Implications for the mechanisms of bioprosthetic tissue mineralization. Amer. J. Pathol. 123, 134-145.

5. Francis, M. D., and Martodam, R. R. (1983). Chemical, biochemical, and medicinal properties of the diphosphonates. In "The Role of Phosphonates in Living Systems" (R. L. Hilderbrand, Ed.), p. 55-96. CRC Press, Boca Raton, FL.

6. Webb, C. L., Benedict, J. J., Schoen, F. J., Linden, J. A., and Levy, R. J. (1988). Inhibition of bioprosthetic heart valve calcification with aminodiphosphonate convalently bound to residual aldehyde groups. Ann. Thorac. Surg. 46, 309-316.

7. KaRNOVSKY, M. J. (1965). A formaldehyde fixative of high osmolality for use in electron microscopy. J. Cell Biol. 27, 137A-138A.

8. Golomb, G., Schoen, F. J., Smith, M. S., Linden, J., Dixon, M., and Levy, R. J. (1987). The role of glutaraldehyde-induced cross-links in calcification of bovine pericardium used in cardiac valve bioprostheses. Amer. J. Pathol. 127(1), 122-130.

9. Carpentier, A., Lemaigre, G., Rober, L., Carpentier, S., and Dubost, C. (1969). Biological factors affecting long-term results of valvular heterografts. J. Thorac. Cardiovasc. Surg. 58(4), 467-483.

10. Cheung, D. T., and Nimni, M. E. (1982). Mechanism of crosslinking of proteins by glutaraldehyde I: Reaction of model compounds. Connect. Tissue Res. 10, 187-199.

11. Bowes, J. D., and CATER, C. W. (1968). The interaction of aldehydes with collagen. Biochim. Biophys. Acta 168, 341-352.

12. WoODROoF, E. A. (1978). Use of glutaraldehyde and formaldehyde to process tissue heart valves. J. Bioeng. 2, 1-9.

13. WebB, C. L., Benedict, J. J., Schoen, F. J., Linden, J. A., and Levy, R. J. (1987). Inhibition of bioprosthetic heart valve calcification with covalently bound aminopropanehydroxydiphosphonate. Trans. Amer. Soc. Artif. Intern. Organs. 10(3), 592-595.

14. Rasmussen, K.-E., and Albrechisen, J. (1974). Glutaraldehyde. The influence of pH, temperature and buffering on the polymerization rate. Histochemistry 38, 19-26.

15. Levy, R. J., Golomb, G., Wolfrum, J., Lund, S. A., Schoen, F. J., and Langer, R. (1985). Local controlled-release of diphosphonates from ethylenevinylacetate matrices prevents bioprosthetic heart valve calcification. Trans. Amer. Soc. Artif. Intern. Organs 31, 459-463.

16. Golomb, G., Dixon, M., Smith, M. S., Schoen, F. J., and Levy, R. J. (1986). Inhibition of bioprosthetic heart valve calcification by sustained local delivery of $\mathrm{Ca}$ and $\mathrm{Na}$ diphosphonate via controlled release matrices. Trans. Amer. Soc. Artif. Intern. Organs 32, 587-590.

17. Golomb, G., Dixon, M., Smith, M. S., Schoen, F. J., and Levy, R. J. (1987). Controlledrelease drug delivery of diphosphonates to inhibit bioprosthetic heart valve calcification: Release rate modulation with silicone matrices via drug solubility and membrane coating. J. Pharm. Sci. 76, 271-276.

18. Schoen, F. J., Kujovich, J. L., WebB, C. L., and Levy, R. J. (1987). Chemically determined mineral content of explanted porcine aortic valve bioprostheses: Correlation with radiographic assessment of calcification and clinical data. Circulation 76, 1061-1066. 